\title{
Market underreaction to open market share repurchases on the JSE
}

\author{
N. Wesson ${ }^{a *}$, C. Muller ${ }^{b}$ and M. Ward ${ }^{b}$ \\ ${ }^{a}$ University of Stellenbosch Business School, South Africa \\ bGordon Institute of Business Science, University of Pretoria, South Africa \\ *To whom all correspondence should be addressed \\ Nicolene.Wesson@usb.ac.zà
}

\begin{abstract}
This study examined the long-term performance of open market share repurchase announcements made by companies listed on the JSE during their reporting periods including 1 July 1999 to 2009. A total of 195 open market share repurchase announcements were identified. A maximum outperformance of about $35 \%$ was found on day $\mathrm{t}+550$ (about two years subsequent to the announcement). After splitting the sample into 'value' (low P/E ratio) and 'growth' shares (high $\mathrm{P} / \mathrm{E}$ ratio), it was found that the outperformance was almost entirely confined to the value portfolio, reaching a maximum of about $80 \%$ by day $\mathrm{t}+630$ (about two-and-a-half years subsequent to the announcement). This study applied a more robust research methodology than used in earlier South African research on this topic; it also used an improved dataset and extended the research period, compared to other research. The results of this study showed much higher positive abnormal returns than were found in earlier international and South African studies. Investors should take advantage of the informational value of open market repurchase announcements and the related significant abnormal returns to be earned.
\end{abstract}

This work is based upon research supported by the National Research Foundation. Any opinion, finding, conclusion or recommendation expressed in this material is that of the authors and the NRF does not accept any liability in this regard.

\section{Introduction}

Share repurchases have globally become an important financial tool for listed companies. In the United States of America (US), share repurchases by companies, except financials and utilities listed on Compustat, equalled dividends for the first time in 1998, overtook dividends in 2005 and widened the margin significantly in 2006 (Dittmar, 2008: 27). European share repurchases accounted for half of the total cash payouts in 2005 and show similar trends to those in the US, although repurchases started much later than in the US (Von Eije \& Megginson, 2008: 348). The open market share repurchase method is by far the most popular method of repurchase, representing $93 \%$ of US repurchase value from 1996 to 2004 (Banyi, Dyl \& Kahle, 2008: 460) and representing $90 \%$ to $95 \%$ of European repurchase value in 1997.

Many studies have been conducted to ascertain the motivation for share repurchases. The most commonly attributed motive is signalling of the company's shares as being undervalued (Dann, 1981; Vermaelen, 1981; Ofer \& Thakor, 1987). In support of the signalling hypothesis, the underreaction hypothesis was postulated by Ikenberry, Lakonishok and Vermaelen (1995), who found that the market treats open market share repurchase programmes with scepticism, leading to prices adjusting slowly over time.

Share repurchases in South Africa were only permitted from 1 July 1999, following the implementation of the Companies
Amendment Act 37 of 1999 (Republic of South Africa, 1999). Limited research has been conducted on share repurchases by companies listed on the JSE; the most notable being that of Daly (2002), Bhana (2007) and Pienaar and Krige (2012). The main reason for limited South African research on share repurchases is the lack of a comprehensive database. The authors of this paper have been able to compile a comprehensive database on share repurchases by JSE-listed companies for reporting periods including 1 July 1999 to 2009.

In this paper we examine the long-term performance (i.e. the underreaction hypothesis) of open market share repurchases by JSE-listed companies over the period 1999 to 2009. We add value to previous South African research by applying a more robust research methodology, using an improved dataset and extending the research period.

\section{Literature review}

\section{Signalling theory}

The explanation most commonly offered in the literature for the repurchasing of shares is that corporate managers use this action to 'signal' to the market their optimism about their company's prospects. The company's management is better informed than outside shareholders about the company's true value, and this information asymmetry can lead to shares being priced below their intrinsic value. Share repurchase plans convey a more credible signal than 
repeated verbal or written statements by management that company shares are undervalued (Miller \& Rock, 1985).

Vermaelen (1981) examined the price behaviour of shares repurchased by companies in the open market. A study of 243 open market offers (made between 1970 and April 1978) by 198 US companies found that open market share repurchases had a cumulative abnormal share price decline of $-6,99 \%$ from $\mathrm{t}-60$ until $\mathrm{t}-2$; from $\mathrm{t}-2$ to $\mathrm{to}$, the two-day average abnormal share return was $3,37 \%$; and the subsequent cumulative abnormal share return decline from $\mathrm{t}+3$ to $\mathrm{t}+60$ was $-1,31 \%$. It was therefore concluded that companies repurchasing their shares were signalling undervaluation to the market.

Ikenberry et al (1995: 183), however, suggested that the positive market reaction of approximately $3 \%$ which was observed in previous studies (Vermaelen, 1981; Lakonishok \& Vermaelen, 1990; Comment \& Jarrell, 1991) was too low. They argued that it hardly seemed plausible that managers would have the ability to recognise such small valuation errors and, also, would choose not to react to such minor discrepancies. Ikenberry et al. (1995) therefore postulated their underreaction hypothesis, i.e. that the initial market reaction is incomplete and that prices adjust slowly over time. They studied 1239 open market share repurchase announcements by US companies between 1980 and 1990 and found a positive immediate return measured from $\mathrm{t}-2$ to $\mathrm{t}+2$ of $3,54 \%$; and a return similar to the market from $\mathrm{t}+3$ to $t+10$. For long-runs over a four-year period after the share repurchase announcement, the cumulative abnormal return moved from $2,04 \%$ after one year to $12,14 \%$ after four years. For companies with high book-to-market ratios (i.e. value shares), the cumulative abnormal returns, over a fouryear period, moved from $4,66 \%$ after one year to $45,29 \%$ after four years. Companies with low book-to-market ratios (i.e. growth shares) did not show positive cumulative abnormal returns. It was thus concluded that, on average, the market underreacts to open market share repurchase announcements and that the full impact of share repurchase announcements can extend over several years, particularly for value shares.

Notable South African studies on the information-signalling hypothesis of open market share repurchases were performed by Daly (2002), Bhana (2007) and Pienaar and Krige (2012). A recent study by Punwasi (2012) tested only the traditional signalling hypothesis. Daly (2002) analysed the share returns of 45 ISE-listed companies that made 88 announcements between 1 July 1999 and 30 September 2001. Bhana (2007) published the first scientific article in South Africa on the same topic, covering the period October 2000 to March 2003, with a sample comprising 117 repurchase announcements. Pienaar and Krige (2012) covered the period October 2000 to December 2007 and analysed 113 transactions made by 63 companies. Punwasi (2012) covered the period January 2003 to August 2012 and analysed 167 amnouncements made by 62 companies that were listed in August 2012 (therefore excluding all announcements made by companies that were delisted during the target period). Daly's, Pienaar and Krige's as well as Punwasi's samples comprised announcements of actual general (or open market) share repurchases, whereas Bhana's sample consisted of general (or open market) repurchase announcements of intention to repurchase, irrespective of whether the repurchases were actually executed (Daly, 2002: 39; Bhana, 2007; 27; Pienaar \& Krige, 2012: 103). The number of announcements of intentions to repurchase via general authority holds little resemblance to the actual number of repurchases that are transacted, because a general offer does not constitute a binding commitment. It has become common practice for companies to obtain authorisation for general share repurchases during annual shareholders' meetings, irrespective of whether they have definite intentions to repurchase shares in the open market (Bester, Wesson \& Hamman, 2010: 50).

The results of Daly's study (2002) were inconclusive owing to the short period under consideration. Bhana (2007) confirmed that the South African market reaction to open market share repurchase announcements is similar to that experienced in the US. The initial abnormal return between $\mathrm{t}-2$ and $\mathrm{t}+2$ was $4,38 \%$; the long-term three-year abnormal return was $14,35 \%$; and for value shares the long-term threeyear abnormal return was $32,8 \%$. Pienaar and Krige (2012) confirmed the results of Bhana (2007) with a long-term three-year abnormal return of $26,57 \%$ for non-resource companies. Pienaar and Krige (2012) did not observe a conclusive result on value versus growth shares. Punwasi (2012: 44) observed a small positive initial abnormal return in the two days following the event of $0,51 \%$.

\section{The South African regulating framework}

There are two methods of share repurchase available to South African companies, namely repurchases under general authority (general repurchases) and repurchases under specific authority (specific repurchases). General repurchases are similar in style to those of American open market share repurchases (Daly, 2002: 13). Regulations on general (or open market) repurchases are more flexible and less cumbersome than specific repurchases, and it is expected that companies would show a preference for open market repurchases over specific share repurchases.

Open market repurchases need to be reported by the company via the Securities Exchange News Service (SENS) of the JSE once it has cumulatively acquired $3 \%$ of its initial number of issued shares (of that class, as at the date of the resolution) and on each $3 \%$ thereafter. The announcement must contain the following; dates of repurchase of shares; highest and lowest price paid; number and value of shares repurchased; extent of authority still outstanding by number and percentage; source of funds utilised; a statement by directors (confirming compliance to the liquidity and solvency requirements); the effect on earnings per share (EPS), headline EPS, net asset value (NAV) and tangible NAV per share, and, if applicable, diluted EPS and diluted headline EPS; and the date on which the shares will be 
cancelled and their listing terminated, if applicable. [Section 11.27 of the JSE Listings Requirements (ISE, 2007)].

Companies repurchasing less than the cumulative 3\% therefore need not announce their open market share repurchases. The $3 \%$ rule however seems to be interpreted as $3 \%$ cumulatively per annum by many companies. While the official stance of the JSE is that the $3 \%$ disclosure requirement is not limited to a specific year, it appears that JSE sponsors advise their clients that the $3 \%$ threshold runs from one annual general meeting, at which shareholders provide the necessary authorisation, to the next (Crotty, 2012). The 3\% announcement rule on open market share repurchases may therefore result in significant understatement of actual open market share repurchase activities.

The $3 \%$ announcement rule on open market repurchases is in contrast with international requirements. Most exchanges require immediate disclosure once the repurchases have been implemented - either on the day preceding the announcement (e.g. in the United Kingdom, Hong Kong, Canada and Australia), a week after the repurchase (e.g. in France) or at the end of the quarter (e.g. in the US, since 2004). Prior to 2004, US companies usually only announced their intention to repurchase in the financial press. (Ginglinger \& Hamon, 2007: 919; Kóbokoane, 2007: 16-17; Mitchell \& Dharmawan, 2007: 149)

Bester et al. (2010) highlighted the fact that the South African share repurchase environment differs from the international environment and that international studies therefore cannot be applied pari passu on South African share repurchases. A sample of 33 ISE-listed companies were studied over nine years, from July 1999 until their reporting periods ending in 2008 , to be able to derive repurchase behaviours and to identify challenges unique to the South African repurchase environment. It was found that open market repurchases represent about $61 \%$ of total share repurchases in value and that only about $49 \%$ of open market repurchases in value are announced via SENS. While this study of 33 companies may not be entirely accurate owing to the relatively small data sample, there is a clear indication that open market share repurchases are not as widely used as in the US and that research based only on 3\% announcements of open market share repurchases results in a significant understatement of actual total share repurchase activities. The South African share repurchase environment therefore presents unique challenges.

\section{Data collection and sample selection}

\section{Data collection}

In this study we investigate the long-term performance (i.e. the underreaction hypothesis) of open market share repurchases by JSE-listed companies for reporting periods including 1999 to 2009 . None of the financial data sources (Reuters, McGregor BFA and I-Net Bridge) has kept detailed records on share repurchase activities for the 11 years (1999 to 2009) covered in this study. Of the previous related South African studies (Daly, 2002; Bhana, 2007; Pienaar \& Krige, 2012; Punwasi, 2012), only Daly included details of his sample. Daly (2002) analysed the share returns of 45 JSE-listed companies that made 88 open market share repurchase announcements between 1 July 1999 and 30 September 2001. Details of repurchase transactions included names of companies, dates of SENS announcements and values of the repurchases. Daly's report could therefore be used as a basis for data collection on announced open market share repurchases. Bester (2008) compared share repurchases with dividends for industrial companies (namely excluding the Basic Materials and Financials sectors) over the period July 1999 to June 2007. He verified and expanded Daly's dataset to include 121 JSE-listed companies making 312 repurchase announcements (open market as well as specific) over the period July 1999 to June 2007. Repurchase details (including names of companies, number of SENS announcements, number of shares repurchased and value of the repurchases) were published in Bester's research report.

Different approaches can be used to obtain a comprehensive dataset on open market repurchases of JSE-listed companies. The first approach followed in this study was to search SENS announcements of companies' repurchase activities as stored in McGregor BFA (product called News). Since the format of the SENS announcements has been inconsistent over time, the following keywords were used to identify the required announcements: 'repurchase', 'buy-back', 'buy back', 'buyback' and 'treasury', Owing to the obvious limitation of the incremental $3 \%$ SENS announcements in respect of open market share repurchases, this data collection approach does not reveal the complete extent of open market share repurchases in South Africa.

The authors adopted a significantly more labour-intensive approach to determine the actual shares repurchased by analysing the annual reports from 1999 to 2009 and noting changes in the number of shares issued. We scanned the directors' reports, share capital notes to the balance sheets and shareholder analyses (or shareholder spreads) of annual reports carefully for changes in issued shares, including treasury shares held by subsidiaries or share trusts. Unfortunately there was no requirement for a separate note in the annual report on share repurchase activities during the target period, therefore we had to consult different sections of the annual report to obtain the repurchase data. Companies do not disclose share repurchase activities in a consistent manner, which complicates the calculation of total share repurchase activities (Bester et al., 2010: 51; Wesson \& Hamman, 2011: 33). We, however, managed to compile reliable data on share repurchases during the target period. (Fortunately, as from 14 January 2013, listed companies have been required to disclose all share repurchases in a separate note in their annual reports [Section 8.63(n) of the Listings Requirements (JSE, 2013)], which will benefit future studies on share repurchases.)

Finally, we followed an extensive verification process to ensure that no repurchase activities had been omitted. This 
process was based on comparing the total share repurchases (as obtained from the annual reports) with the announced share repurchases (as derived from the SENS announcements) to verify that all announcements correspond to actual share repurchases as disclosed in the annual reports. We could therefore make a distinction (in number of shares and rand values) between open market and specific share repurchases, as well as between announced and unannounced share repurchases.

Although the data collection process uncovered all open market repurchases during the target period, we used only the announced open market repurchases in this study. The event date is the announcement date (on SENS) of the share repurchase. No repurchase date is disclosed by reporting entities in their annual reports during the target period and therefore unannounced share repurchases do not have an event date to be used when testing the underreaction hypothesis.

The open market share repurchase data in this study are an improvement on the previous datasets used in South African studies on the underreaction hypothesis of open market repurchases. In this study we verified all SENS announcements to ensure that they represent actual share repurchases.

The following are examples of announcements which were excluded:

- Repeat announcements where companies announce the same share repurchase more than once in SENS (this study only included the first and actual share repurchases);

- Fraudulent announcements of share repurchases (e.g. three announcements by Control Instruments in 2008 which were uncovered during the annual audit);

- Announcements of share repurchases which occurred subsequent to the publication of the final annual report, but before the delisting of the company, and which could not be verified with the daily movement in number of shares as obtained from McGregor BFA (product called Price Data). (All announcements of share repurchases by subsidiaries before delisting, but subsequent to the final anmual report of their holding company, were excluded from the dataset as only daily movements in the number of holding company shares are captured in McGregor BFA - product called Price Data.)

Although many of the SENS announcements on open market share repurchases do not include all the information as required by section 11.27 of the JSE Listings Requirements (JSE, 2007), these announcements were included in the dataset for announced open market repurchases if enough detail was disclosed to identify the date, number of shares and repurchasing entity (i.e. holding company or subsidiary) and the announcement represented actual repurchases (as discussed above),

\section{Sample selection}

The following JSE-listed companies are included in this study for reporting periods including 1 July 1999 until the 2009 year-end of the company:

- Companies with listed ordinary and/or N-class shares;

- Companies with the JSE as their primary listing; and

- Companies listed on the Main Board, except for companies listed in the Basic Materials and Financials sectors of the JSE.

We did not treat odd lot offers as share repurchases as they had existed prior to 1999. We also excluded companies that fell within the sample requirements but were listed for fewer than three years. Share trust repurchases were also excluded as legal requirements on share repurchases in the Companies' Act and JSE Listings Requirements are not applicable to share trust repurchases.

From 1999 to 2009 , there were 227 companies (as defined in the sample selection) listed on the JSE, of which 87 were delisted during the period. We included delisted companies (up to the date of their delisting) to ensure a comprehensive study of repurchase activities.

During the target period, 195 open market repurchase announcements were made by 69 companies. Appendix 1 lists the names of the 69 companies that made open market share repurchase announcements during their reporting periods including 1 July 1999 until their 2009 financial yearend. Appendix 2 lists the number of open market share repurchase announcements per annum (based on reporting periods) and the rand values thereof.

\section{Methodology}

A standard methodology for event studies has been established over time (Brown \& Warner, 1980; Bowman, 1983; Madura \& Akhigbe, 1995; Bhana, 1998). This methodology is broadly applied in this study, with some differences as discussed below.

Lyon, Barber and Tsai (1999: 165) note that the analysis of long-term abnormal returns is "treacherous". Therefore, an important consideration for event studies, and particularly for long-term studies, is the choice of benchmark against which abnormal returns are estimated. Many event studies use a market- or single-parameter CAPM model as the benchmark, but this has been shown to be inadequate. In particular, the CAPM fails to account for expected returns on the basis of company size, as well as growth versus value (Fama \& French, 1992, 1993, 1995, 1996, 1998) and, in the South African context, a further consideration is 'resource' versus 'non-resource' shares (Van Rensburg 2001; Van Rensburg \& Robertson, 2003a, 2003b). Accordingly, a 12parameter 'style' model to estimate benchmark returns was used in this study. Following Mordant and Muller (2003), Mutooni and Muller (2007), and Ward and Muller (2010), we created 12 'control portfolios' of shares representing the 
cross-sectional factors of size, growth/value and resources/non-resources - as shown in Table 1 . The crosssectional factors were established as follows:

- A company's size was measured by its market capitalisation. All the companies listed on the JSE and included in the Financial Times and Stock Exchange (FTSE)/JSE All Share Index (usually about 160 companies) were ranked in descending order of market capitalisation. The 40 shares with the largest market capitalisation constituted the large capitalisation control portfolio. Shares with a market capitalisation ranking from 41 to 100 constituted the medium capitalisation control portfolio, and the remaining 60 shares formed the small capitalisation control portfolio.

- A company was classified as a growth or a value investment in terms of its price-to-earnings $(\mathrm{P} / \mathrm{E})$ ratio. The $\mathrm{P} / \mathrm{E}$ ratios were calculated and ranked, after which the median was determined. All companies with $\mathrm{P} / \mathrm{E}$ ratios above the median were classified as growth and the remainder as value.

- The broad JSE sector groupings were used as criteria to decide whether shares represented a 'resource' share or not. All mining and non-mining resource shares were classified as resources, while the rest of the market was classified as non-resources.

Each share listed on the JSE was placed into one of the 12 control portfolios, depending on its characteristics. For example, Sasol Ltd. would classify as Large, Resource and Value or Growth depending on whether its $\mathrm{P} / \mathrm{E}$ ratio was below or above the median $\mathrm{P} / \mathrm{E}$ ratio at the start of a particular quarter. The control portfolios were rebalanced every quarter to ensure that changes in share characteristics $(\mathrm{P} / \mathrm{E}$ ratios, market capitalisations, new listings and delistings, etc.) were closely tracked over time. Delisted shares were included up to the date of termination of trading, after which the share price returns of the delisted companies were assumed to be zero until the end of the quarter. The delisted shares were excluded from the following quarter's rebalancing of control portfolios. Similarly, the share price returns of newly listed shares were included in the following quarter, when the control portfolios were rebalanced.
Table 1: Control portfolios

\begin{tabular}{|c|c|c|c|}
\hline $\begin{array}{l}\text { Control } \\
\text { portfolio }\end{array}$ & $\begin{array}{c}\text { Large, medium } \\
\text { or small size }\end{array}$ & $\begin{array}{l}\text { Value or } \\
\text { growth } \\
\text { company }\end{array}$ & $\begin{array}{c}\text { Resources or } \\
\text { non-resources } \\
\text { company }\end{array}$ \\
\hline SGN & Small & Growth & Non-resources \\
\hline SGR & Small & Growth & Resources \\
\hline SVN & Small & Value & Non-resources \\
\hline SVR & Small & Value & Resources \\
\hline $\mathrm{MGN}$ & Medium & Growth & Non-resources \\
\hline MGR & Medium & Growth & Resources \\
\hline $\mathrm{MVN}$ & Medium & Value & Non-resources \\
\hline MVR & Medium & Value & Resources \\
\hline LGN & Large & Growth & Non-resources \\
\hline LGR & Large & Growth & Resources \\
\hline LVN & Large & Value & Non-resources \\
\hline LVR & Large & Value & Resources \\
\hline
\end{tabular}

We constructed daily equal-weighted indices for each of the 12 control portfolios using $\log$ returns - as summarised in Equation 1.

$$
R_{i t}=\log \left[\mathrm{P}_{i t} / \mathrm{P}_{i t-1}\right]
$$

where:

$\mathrm{R}_{\mathrm{it}}=$ the equal-weighted share return for portfolio $i$ for day $t$, and

$P_{\text {it }}=$ the equal-weighted share value of portfolio $i$ at the end of day $t$.

Following Mordant and Muller (2003), we then calculated beta coefficients for each share in the event sample by regressing each share's monthly log-function share price return over the preceding 48 -month period against the monthly returns of each of the 12 control portfolios for the matching period. The result was a regression equation (Equation 2) for each selection. We also obtained an alpha coefficient for each share from the regression equation and included these in the estimation of expected returns, after adjusting for daily intervals. Alpha and beta parameters for each share in the sample were updated on a rolling monthly basis using prior data.

The control portfolio model measures the expected return of share $i$ in period $t$ as the sum of the sensitivity of share $i$ to the returns on the 12 control portfolios and a calculated daily alpha estimate in period $t$. This is summarised in Equation 2:

$$
\begin{aligned}
\mathrm{E}\left(R_{i t}\right)=\alpha_{i, t}+ & \beta_{\mathrm{i}, 1} \mathrm{SGN}_{t}+\beta_{\mathrm{i}, 2} \mathrm{SGR}_{t}+\beta_{\mathrm{i}, 3} \mathrm{SVN}_{t} \\
& +\beta_{\mathrm{i}, 4} \mathrm{SVR}_{t}+\beta_{\mathrm{i}, 5} \mathrm{MGN}_{t} \\
& +\beta_{\mathrm{i}, 6} \mathrm{MGR}_{t}+\beta_{\mathrm{i}, 7} \mathrm{MVN}_{t} \\
& +\beta_{\mathrm{i}, 8} \mathrm{MVR}_{t}+\beta_{\mathrm{i}, 9} \mathrm{LGN}_{t} \\
& +\beta_{\mathrm{i}, 10} \mathrm{LGR}_{t}+\beta_{\mathrm{i}, 11} \mathrm{LVN}_{t} \\
& +\beta_{\mathrm{i}, 12} \mathrm{LVR}_{t}
\end{aligned}
$$


where:

$$
\begin{aligned}
& E\left(R_{j i}\right)=\text { the expected return on share } i \text { on day } t \text {; } \\
& \text { 话, = the alpha intercept term of share i on day } t \text {, } \\
& \beta_{i n 1}, \beta_{i 12}=\text { the beta coefficients on each control }
\end{aligned}
$$

Next we ealeulated daily abnormal returns (ARs) in terms of Equation 3, and then averaged them across the sample for the event analysis

$$
A\left(R_{i t}\right)=R_{i k} \quad E\left(R_{i t}\right)
$$

where:

$$
\begin{aligned}
& \mathrm{AR}_{\mathrm{i} 1}=\text { the abnormal return of share } i \text { in period } t_{i} \\
& E\left(R_{i j}\right)=\text { the expected share price return of share } i \text { in } \\
& \text { period t determined in terms of } \\
& \text { Equation 2; and } \\
& \mathrm{R}_{\mathrm{il}}=\text { aetual return of share } i \text { in period } t \text {. }
\end{aligned}
$$

We ealculated performance over an extended period by aceumulating the average abnormal retums to obtain the cumulative abnormal return (CAR) for each share, over the event window period.

\section{Hypothesis testing}

Brown and Wamer (1980, 1985) present the most commonly ustd parametric tests to measure significance on ARs from eyent studies. MeWilliams and MeWilliams (2000) present an aggegated z-test for cumulative abnornal returns (CARs), provided these are normally distributed. Sanger and McConnell (1986), Corrado (1989) and Cowan and Sergeant (1996) all offer appropriate nom parametric tests: A bootstrapping process to test ARs and CARs for significance was applied in the present study (Noreen, 1989)

Using the daily ARs on each of the ahares in the sample, we constructed Monte Curlo-type bootstrap distributions of CARs. This was done by selecting tandom dates, for each company, from the period before and after the actual event date (excluding the observations in the event window itself) and ealeulating the CARs We repeated the randorn date generation proets 200 times to generate a guite of distributions for the event window From this data we determined significanet levets. The ARs over the event period could then also be tested for significance. This method of significance testing is siqerior te the $t$-test in that no assumption is made of normality. We used the bootstrap distributions for -60-day CARs, 10-day CARs, 20-day CARs, 60-day CARs and 550-day CARs and tested the sample CARs for significance.

\section{Results}

Figure I shows the CARs for the sample over an event windosw from $t-60$ to $t+60$. Since the days are measured as working days, this represents a period of about three months prior to the announcement date to and a post-event period of about three months. We centred the CARs at day to. accumlating the ARs backwards to $t-60$ and forwards to t+60. We showed the simple average of the CARs, as well as the effect of weighting tach observation as the value of the repurthase as a pereentage of the market capitalieation of the company.

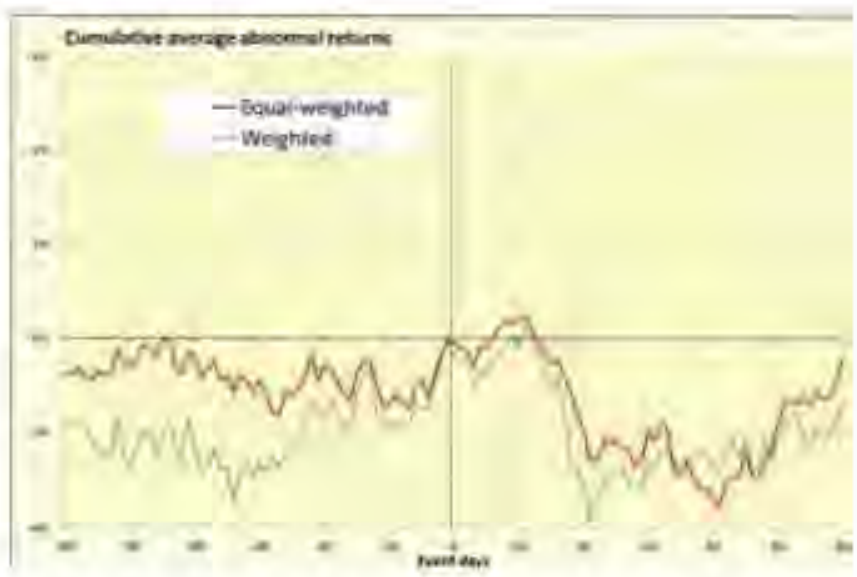

Figure 1: Average CARs for share repurchase announcements

From Figure 1 we observed various fluetiations for the equal-weighted sample. Prior to the annoumeement date, the CARs remained marginally below zero at about $-1 \%$ In the days surrounding the event itself, $t-3$ to $t+3$, we observed a small increast of about $1 \%$. In the period following the announcement, from $t+10$ to $t+22$, the CARs doclined a further $2 \%$. From about $t+20$ intil about $t+50$ the CARs arr steady at about $-2 \%$ and appreciate slowly, ending at about $0 \%$ on $t+60$. We observed very little difference in the weighted sample compared to the equal-wtighted sample

Io obtain a better idea of the long-term effects, we repeated the analysis over a much longer event window, from $t-60$ to $1+720$, that is approximately three months prior to the announeement, until thret years after the anno uncement. 


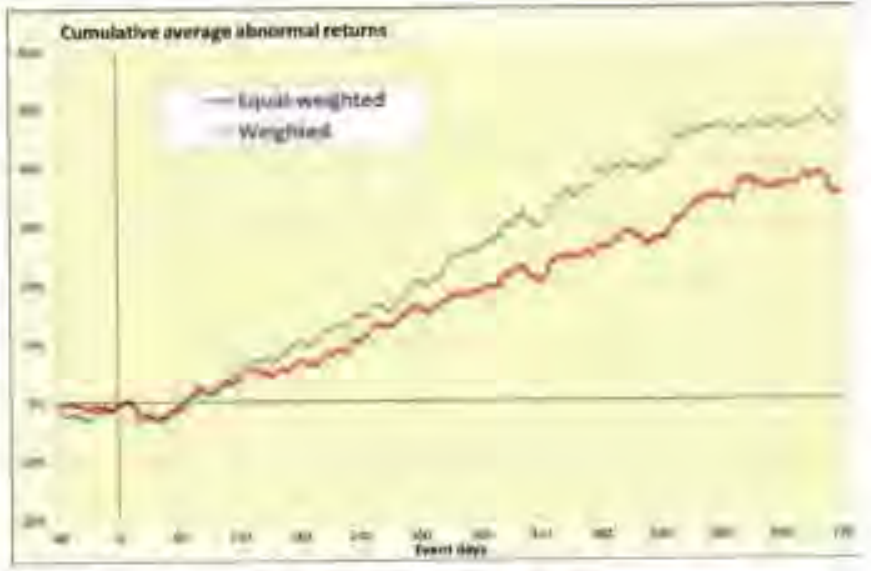

Figure 2: Lonz-ter an CARs for share repurchase announcements

In Figure 2 we were able to see the long-term effects, and we observed that from about $t+50$ the CARs steadily increased to about $35 \%$ at about $t+600$ before the trend dissipated for the equal-weighted sample. In the weighted sample the CARs followed a similar pattem, but inereased to about $48 \%$ at about $t+550$. 'Thereafter the trend was almost flat.

To test for significance in the CARs, a Monte Carlo analysis was conducted on the equal-weighted sample using randorn dates, as described eartier. Figure 3 shows the results, with the maximum, median, minimum, and the 10 th and 90 th percentiles plottod

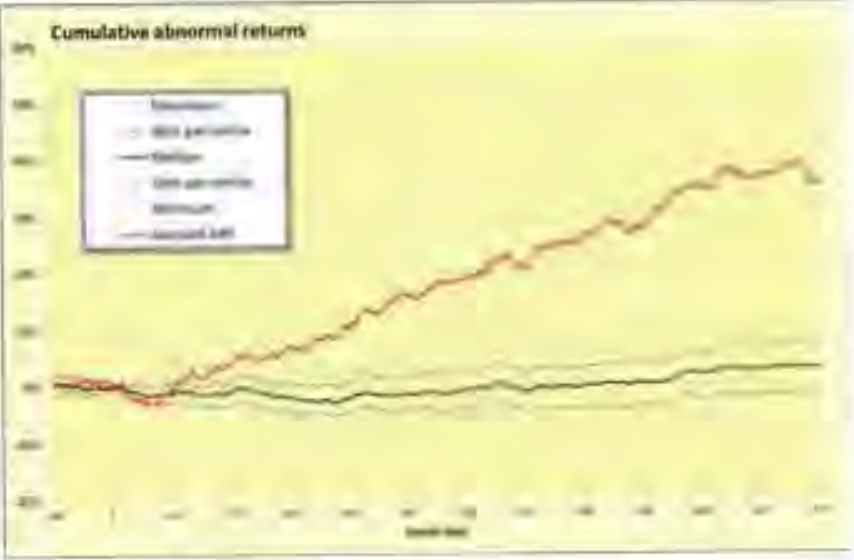

Figure 3: Confidence limits around the equal-weighted sample CARs

From Figure 3 it ean be observed that the sample CARs remained bounded within the 10 th and 90 th percentiles until about $t+80$. Thereafter equal-weighted sample CARs remained significantly figher than the maximum values obtained in the bootstrap distributions.

Table 2 shows the relevant statistics for the significance tests (all of which were conducted on the equal-weighted data set).
Table 2: Significance test results

\begin{tabular}{|c|c|c|c|c|c|c|}
\hline Event date & $t-60$ & to & $t+10$ & +20 & $1+60$ & $t+550$ \\
\hline $\begin{array}{l}\text { Mente Carlo } \\
\text { maximan } \%\end{array}$ & 2,41 & 035 & 1,24 & 1,34 & 1,79 & 6,07 \\
\hline $\begin{array}{l}\text { Morte Carlo } \\
\text { minimim } \%\end{array}$ & $-2,43$ & 0,52 & $-1,69$ & $-2,77$ & 4,11 & $-6,46$ \\
\hline $\begin{array}{l}\text { Monte Carlo } \\
\text { mean } \% \text {. }\end{array}$ & $-0,10$ & $-0,08$ & $-0,08$ & $-0,82$ & $-1,67$ & 0,04 \\
\hline CAR value \% & 0.98 & $-0,08$ & 0.48 & .195 & $-0,35$ & 2918 \\
\hline Percentile $\%$ & 7000 & 50,00 & 70,00 & 15,00 & 60,00 & 100,00 \\
\hline
\end{tabular}

From Table 2 we observed at $\mathrm{t}-60$ the CAR for the sample was $0,98 \%$, which was around the 70 th pereentile of the distribution generated by the 200 randorn simulations. indicating that the deoline from $t-60$ to tol was not sigrificant. The CAR at to was $-0,08 \%$, and we concluded that this was not significantly different from the Monte Carto mean of $-0,08 \%$ using sinulations.

At $t+10, t+20$ and $t+60$ our results were also not statistically significant. However, at $t+550$ our sample CAR was $29,18 \%$, whereas our highest simulation result for CARs at $t+550$ was $6,07 \%$. We concluded that there was a significant postive outperformance in the share repurchase sample over the 550 trading days following the announcement.

Finally, we split the sample into two equal-sized portfolios by ranking the companits by their $\mathrm{P} / \mathrm{E}$ ratio at the announcement date, the bw $\mathrm{P} / \mathrm{E}$ sample represtnting a value portfolio and the high $P / E$ sample representing growth

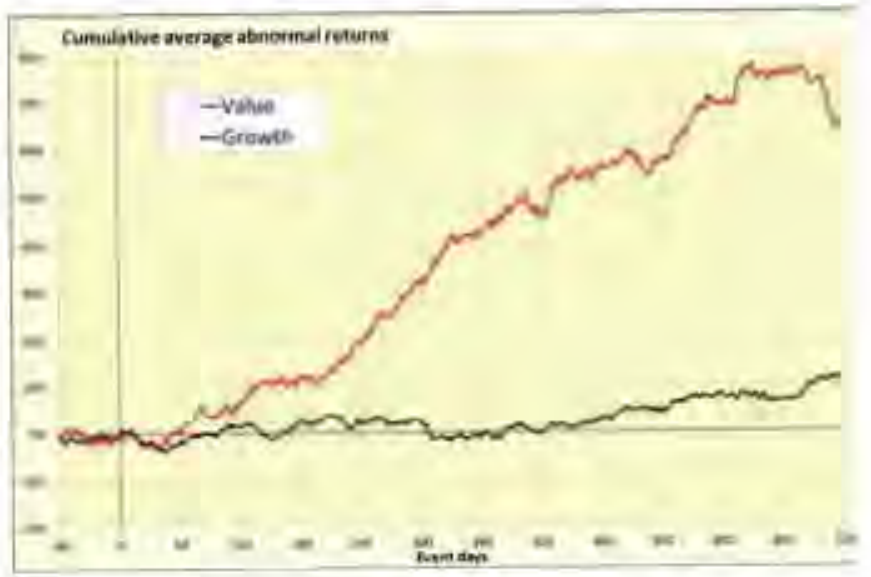

Figure 4: CARs for the sample split into value and growth portfolies

From Figure 4 we observed a similar pattem for the CARs of the value and growth portfolios until about t+40. Thereafter the CARs for the value portfolio grew rapidly over the next three years to about $80 \%$ by $t+630$, before the trend subsided. The CARs for the growth portfolio remained flat, around $0 \%$, trending stightly upwards from $t+420$ to about $10 \%$ at $t+720$

We also ranked companies by their market-to-book ratio at the announcement date. The market-to-book ratio used represents the ratio at the year-end preceding the 
announcement date and was calculated by dividing the market capitalisation (as obtained from McGregor BFA product called Price Data) by the ordinary shareholders' capital (as obtained from McGregor BFA - product called Financial Statements). A market-to-book ratio below 1 represents a value portfolio and a market-to-book ratio above 1 represents a growth portfolio. Similar results to the $\mathrm{P} / \mathrm{E}$ ratio ranking were obtained: CARs for the value portfolio grew rapidly from announcement date to just above $60 \%$ by $\mathrm{t}+600$, after which the trend subsided; the CARs for the growth portfolio remained flat, around $0 \%$, trending slightly upwards from $\mathrm{t}+240$ to about $20 \%$ at $\mathrm{t}+720$.

\section{Conclusions}

We identified 195 open market share repurchase announcements over the period 1 July 1999 to the 2009 financial year-ends of JSE-listed companies included in this study. Following the control portfolio event study method of Ward and Muller (2010), we estimated daily CARs for the sample using an event window of 60 trading days (approximately three months) prior to the announcement date to 720 trading days (about three years) after the event. We conducted the analysis using an equal-weighted sample and a sample in which the observations were weighted by the value of the share repurchase as a percentage of the company's market capitalisation. Our results (which were similar for both samples) showed that in the three months prior to the announcement of a share repurchase, the shares were relatively stable with a negative CAR of between $-1 \%$ and $0 \%$. In the period around the event date, the CARs increased by about $1 \%$, but this was not statistically significant. Between $\mathrm{t}+10$ and $\mathrm{t}+22$ the CARs dropped by a further $2 \%$, but this again was not statistically significant. From about $t+50$, however, we observed a steady increase in the CARs, which reached a maximum of about $35 \%$ (for the equal-weighted sample) and $48 \%$ (for the weighted sample) outperformance on about $t+550$. Using bootstrap distributions, we found the outperformance at $t+550$ to be highly significant. The fact that the weighted sample outperforms the equal-weighted sample indicates that the higher the percentage of shares repurchased as a percentage of market capitalisation, the stronger the effect.

We repeated the analysis after splitting the sample into 'value' (low P/E) and 'growth' (high P/E) shares and found that the outperformance was almost entirely confined to the value portfolio, reaching a maximum of about $80 \%$ by $\mathrm{t}+630$ (after about two-and-a-half years), before the trend subsided. While this raised the possibility that we were simply measuring a value effect in our analysis, we dismissed this as unlikely, given that we had controlled for this in the construction of our control portfolios to estimate the ARs.

This study supports the findings of previous studies on the positive long-term performance of open market share repurchases. A US study by Ikenberry et al. (1995) reported abnormal returns of about $12 \%$ over a four-year period, with value shares showing abnormal returns of about $45 \%$ over a four-year period. Previous South African research (Bhana,
2007; Pienaar \& Krige, 2012) also supported abnormal returns over the long term: Bhana (2007) reported abnormal returns of about $14 \%$ over a four-year period, with value shares showing abnormal returns of about $33 \%$ over a fouryear period; while Pienaar and Krige (2012) reported abnormal returns of about $27 \%$ over a three-year period, but did not observe a conclusive difference between value versus growth shares.

This study applied a more robust research methodology than was applied in previous studies on the long-term performance of open market share repurchases. The study also used an improved dataset over an extended research period, when compared to prior South African research on the long-term performance of open market share repurchases. This study found a much higher positive abnormal return of about $35 \%$ after about two years (after which the trend flattened) than had been observed in prior international and local research. The positive abnormal return was mainly confined to value shares, which showed an abnormal return of about $80 \%$ after about two-and-a-half years, before subsiding.

This study therefore confirms that investment decisions based on open market share repurchase announcements, especially in respect of value shares, have earned significant abnormal returns for a period of about three years subsequent to the announcement date. Investors should therefore take advantage of the informational value of open market share repurchase announcements.

Future studies should address comparative assessments of different return estimation models (e.g. the standard CAPM model, a model incorporating a momentum factor in the control portfolios and a model applying value proxies other than $\mathrm{P} / \mathrm{E}$ ratios in the value/growth control portfolios) on the market underreaction to open market share repurchases on the ISE.

\section{References}

Banyi, M.L., Dyl, E.A. \& Kahle, K.M. 2008. 'Errors in estimating share repurchases', Journat of Corporate Finance, 14(4): 460-474.

Bester, P.G. 2008. 'Shareholder distribution choices for industrial companies listed on the JSE: Share buybacks vs. dividends'. Unpublished MBA research assignment. Bellville: University of Stellenbosch.

Bester, P.G., Wesson, N. \& Hamman, W.D. 2010. 'Share buy-backs for a selection of JSE-listed companies: An exploratory study', South African Joumal of Business Management, 41(4): 47-58.

Bhana, N. 1998. 'Share price reaction to announcements of equity financing by companies listed on the Johannesburg Stock Exchange', Investment Analysts Journal, 48: 35-44. 
Bhana, N. 2007. "The market reaction to open market share repurchases announcements: The South African experience', Investment Analysts Journal, 65: 25-36.

Bowman, R. 1983. 'Understanding and conducting event studies', Joumal of Business and Financial Accounting, 10(4); 561-584.

Brown, S.J. \& Warner, J.B. 1980. 'Measuring security price performance', Journal of Financial Economics, 8(3): 205258.

Brown, S.J. \& Warner, J.B, 1985. 'Using daily stock returns: The case of event studies', Journal of Financial Economics, 14(1): 3-31.

Corrado, C.J. 1989. 'A nonparametric test for abnormal security-price performance in event studies', Journal of Financial Economics, 23(2): 385-395.

Cowan, A.R. \& Sergeant, A.M.A. 1996. 'Trading frequency' and event study test specification', Journal of Banking \& Finance, 20(10): 1731-1757.

Comment, R. \& Jarrell, G.A. 1991. 'The relative signalling power of Dutch-auction and fixed-price self-tender offers and open-market share repurchases', Journal of Finance, 46(4): 1243-1271.

Crotty, A. 2012. 'JSE eyes tight rules', Business Report, 26 June [online] URL: http://www.iol.co.za/business/businessnews/jse-eyes-tight-rules-1.1327435.

Daly, K.J. 2002. 'Share returns of companies announcing share repurchases under a general authority". Unpublished research report, February. Johannesburg: University of the Witwatersrand.

Dann, L.Y. 1981، 'Common stock repurchases: An analysis of returns to bondholders and stockholders', Journal of Financial Economics, 9(2): 113-138.

Dittmar, A.K. 2008. 'Corporate cash policy and how to manage it with stock repurchases", Journal of Applied Corporate Finance, 20(3): 22-34.

Fama, E.F. \& French, K.R. 1992. "The cross-section of expected stock returns', Journal of Finance, 47(2): 427-465.

Fama, E.F. \& French, K.R. 1993. 'Common risk factors in the returns of stocks and bonds', Journal of Financial Economics, 33(1): 3-56.

Fama, E.F. \& French, K.R. 1995. 'Size and book-to-market factors in earnings and returns', Journal of Finance, 50(1): 131-155.

Fama, E.F. \& French, K.R. 1996. 'Multifactor explanations of asset pricing anomalies', Journal of Finance, 51(1): 5584.
Fama, E.F. \& French, K.R. 1998. 'Value versus growth: The international evidence', Journal of Finance, 53(6): 19751999.

Ginglinger, E. \& Hamon, J. 2007. 'Actual share repurchases, timing and liquidity, Journal of Banking \& Finance, 31(3): 915-938.

Ikenberry, D., Lakonishok, J. \& Vermaelen, T. 1995. 'Market underreaction to open market share repurchases', Journal of Financial Economics, 39(2-3): 181-208.

JSE. 2007. JSE Listings Requirements. Service Issue no 3. Johannesburg: LexisNexis Butterworths. [online] URL: http://www.jse.co.za/listing_requirements.jsp.

JSE. 2013. JSE Listings Requirements. Service Issue no 16. Johannesburg: LexisNexis Butterworths. [online] URL: http://www.jse.co.za/How-To-List/Listing-requirements/ JSE-listing-requirements.aspx.

Kobokoane, N. 2007. 'Share buybacks in South Africa: An empirical investigation'. Unpublished MBA research report. Bellville: University of Stellenbosch.

Lakonishok, J. \& Vermaelen, T. 1990. 'Anomalous price behaviour around repurchase tender offers', Journal of Finance, 45(2): 455-477.

Lyon, J.D., Barber, B.M. \& Tsai, C-L. 1999. 'Improved methods for tests of long-run abnormal stock returns', Journal of Finance, 54(1): 165-201.

Madura, J. \& Akhigbe, A. 1995. Influence of economic factors on the valuation effects of debt offerings", Applied Economics, 27:907-915.

McWilliams, T.P. \& McWilliams, V.B. 2000. 'Another look at theoretical and empirical issues in event study methodology ${ }^{*}$ Journal of Applied Business Research, 16(3): $1-11$.

Miller, M.H. \& Rock, K. 1985. 'Dividend policy under asymmetric information', Journal of Finance, 40(4): 10311051.

Mitchell, J.D. \& Dharmawan, G.V. 2007. 'Incentives for onmarket buy-backs: Evidence from a transparent buy-back regime', Journal of Corporate Finance, 13(1); 146-169.

Mordant, N. \& Muller, C. 2003. 'Profitability of directors' share dealings on the JSE', Investment Analysts Joumal, 57: $17-32$.

Mutooni, R. \& Muller, C. 2007. 'Equity style timing', Investment Analysts Journal, 65: 15-24.

Noreen, E. 1989. Computer intensive methods for testing hypotheses. New York: John Wiley \& Sons. 
Ofer, A.R. \& Thakor, A.V. 1987. "A theory of stock price responses to alternative corporate cash disbursement methods: Stock repurchases and dividends', Journal of Finance, 42(2): 365-394.

Pienaar, H.P. \& Krige, J.D. 2012. 'Market reaction to open market share repurchases on the Johannesburg Stock Exchange over the period 2000 to $2007^{\prime}$, Studies of Economics and Econometrics, 36(3): 101-122.

Profile Media. 2010. Profile's Stock Exchange Handbook, February - May. Pietermaritzburg, Kwazulu-Natal: Pintrepid Printers.

Punwasi, K. 2012. 'An event study: The market reactions to share repurchase announcements on the JSE'. Unpublished MBA research report. Pretoria: University of Pretoria's Gordon Institute of Business Science.

Republic of South Africa. 1999. Companies Amendment Act, no. 37 of 1999. Pretoria: Government Printer.

Sanger, G.C. \& McConnell, J.J, 1986. 'Stock exchange listings, firm value and security market efficiency: The impact of NASDAQ', Journal of Financial and Quantitative Analysis, 21(1): 1-25.

Van Rensburg, P. 2001, 'A decomposition of style-based risk on the JSE', Investment Analysts Joumal, 54: 45-60.

Van Rensburg, P. \& Robertson, M. 2003a. 'Style characteristics and the cross-section of JSE returns', Investment Analysts Journal, 57: 1-10.

Van Rensburg, P. \& Robertson, M. 2003b. 'Size, price-toearnings and beta on the JSE', Investment Analysts Journal, 58: $1-13$.

Vermaelen, T. 1981. 'Common stock repurchases and market signalling: An empirical study, , Journal of Financial Economics, 9(2): 139-183.

Von Eije, H. \& Megginson, W.L. 2008. 'Dividends and share repurchases in the European Union', Joumal of Financial Economics, $89(2) ; 347-374$.

Ward, M. \& Muller, C. 2010. 'The long-term share price reaction to Black Economic Empowerment announcements on the JSE, Investment Analysts Journal, 71: 27-36.

Wesson, N. \& Hamman, W.D. 2011. 'Disclosure of share capital: Are reporting standards clear?' Accountancy $S A$, February: 32-34

\section{Apendices}

\begin{tabular}{|c|c|c|}
\hline \multicolumn{3}{|c|}{$\begin{array}{l}\text { Appendix } 1 \\
\text { Companies making open market share repurchase } \\
\text { announcements }\end{array}$} \\
\hline & Company name* & $\begin{array}{c}\text { Number of } \\
\text { announcemen } \\
\text { ts }\end{array}$ \\
\hline 1 & AdaptIT Holdings Ltd & 5 \\
\hline 2 & Adcorp Holdings Ltd & 1 \\
\hline 3 & AFGRI Ltd & 2 \\
\hline 4 & Astral Foods Ltd & 3 \\
\hline 5 & Astrapak Ltd & 1 \\
\hline 6 & Aveng Ltd & 1 \\
\hline 7 & AVI Ltd & 2 \\
\hline 8 & Barloworld Ltd & 3 \\
\hline 9 & Brandcorp Holdings Ltd & 4 \\
\hline 10 & Business Connexion Group Ltd & 6 \\
\hline 11 & Cashbuild Ltd & 1 \\
\hline 12 & Chester Investment Holdings Ltd & 1 \\
\hline 13 & Clicks Group Ltd & 9 \\
\hline 14 & Compu-Clearing Outsourcing Ltd & 5 \\
\hline 15 & Connection Group Holdings Ltd & 2 \\
\hline 16 & Digicore Holdings Ltd & 2 \\
\hline 17 & Distribution and Warehousing Network Ltd & 3 \\
\hline 18 & Edgars Consolidated Stores Ltd & 4 \\
\hline 19 & Ellerine Holdings Ltd & 1 \\
\hline 20 & EnviroServ Holdings Ltd & 2 \\
\hline 21 & EOH Holdings Ltd & 1 \\
\hline 22 & Excellerate Holdings Ltd & 1 \\
\hline 23 & Faritec Holdings Ltd & 2 \\
\hline 24 & Foschini Ltd & 3 \\
\hline 25 & Grindrod Ltd & 6 \\
\hline 26 & Hudaco Industries Ltd & 1 \\
\hline 27 & Illiad Africa Ltd & 6 \\
\hline 28 & Imperial Holdings Ltd & 2 \\
\hline 29 & Inmins Ltd & 2 \\
\hline 30 & Invicta Holdings Ltd & 4 \\
\hline 31 & IST Group Ltd & 1 \\
\hline 32 & JD Group Ltd & 1 \\
\hline 33 & KayDav Group Ltd & 2 \\
\hline 34 & Kelly Group Ltd & 1 \\
\hline 35 & LA Group Ltd & 10 \\
\hline 36 & Lewis Group Ltd & 3 \\
\hline 37 & Malbak Ltd & 3 \\
\hline 38 & Mustek Ltd & 4 \\
\hline 39 & Mvelephanda Group Ltd & 2 \\
\hline 40 & Ozz Ltd & 3 \\
\hline 41 & Paracon Holdings Ltd & 2 \\
\hline 42 & Phumelela Gaming and Leisure Ltd & 1 \\
\hline 43 & Pick n Pay Stores Ltd & 1 \\
\hline 44 & Pinnacle Technology Holdings Ltd & 1 \\
\hline 45 & Pretoria Portland Cement Company Ltd & 2 \\
\hline 46 & Primedia Ltd & 2 \\
\hline 47 & Primeserv Group Ltd & 4 \\
\hline 48 & Profurn Ltd & 1 \\
\hline 49 & Remgro Ltd & 2 \\
\hline 50 & Reunert Ltd & 3 \\
\hline 51 & Sasani Ltd & 1 \\
\hline 52 & Sasol Ltd & 5 \\
\hline 53 & SecureData Holdings Ltd & 1 \\
\hline 54 & Spur Corporation Ltd & 1 \\
\hline 55 & Steinhoff International Holdings Ltd & 1 \\
\hline 56 & Super Group Ltd & 3 \\
\hline
\end{tabular}




\begin{tabular}{c|l|c}
\hline 57 & Telkom SA Ltd & 6 \\
\hline 58 & The Bidvest Group Ltd & 1 \\
\hline 59 & The House of Busby Ltd & 5 \\
\hline 60 & The Laser Group Ltd & 2 \\
\hline 61 & Tiger Brands Ltd & 1 \\
\hline 62 & Tourism Investment Corporation Ltd & 1 \\
\hline 63 & Transpaco Ltd & 1 \\
\hline 64 & Truworths International Ltd & 13 \\
\hline 65 & UCS Group Ltd & 4 \\
\hline 66 & Unitrans Ltd & 1 \\
\hline 67 & Universal Industries Corporation Ltd & 3 \\
\hline 68 & Value Group Ltd & 2 \\
\hline 69 & Woolworths Holdings Ltd & 195 \\
\hline & Total number of announcements & Ferngry \\
\hline
\end{tabular}

*Company names as per Profile's Stock Exchange Handbook, February 2010 - May 2010 (Profile Media, 2010)

\begin{tabular}{|c|c|c|c|c|}
\hline \multicolumn{5}{|c|}{$\begin{array}{l}\text { Open market share repurchase announcements per } \\
\text { annum (based on reporting periods) }\end{array}$} \\
\hline Year & $\begin{array}{c}\text { Number of } \\
\text { announcements }\end{array}$ & $\%$ & Rand values & $\%$ \\
\hline 1999 & 0 & 0,00 & 0 & 0,00 \\
\hline 2000 & 14 & 7,18 & 2461253199 & 7,19 \\
\hline 2001 & 38 & 19,49 & 1293448616 & 3,78 \\
\hline 2002 & 29 & 14,87 & 1917650818 & 5,61 \\
\hline 2003 & 31 & 15,90 & 1207763113 & 3,53 \\
\hline 2004 & 7 & 3,59 & 1074200050 & 3,14 \\
\hline 2005 & 13 & 6,67 & 3266258735 & 9,55 \\
\hline 2006 & 12 & 6,15 & 3783765734 & 11,06 \\
\hline 2007 & 12 & 6,15 & 6482967599 & 18,95 \\
\hline 2008 & 28 & 14,36 & 12033931555 & 35,18 \\
\hline \multirow[t]{2}{*}{2009} & 11 & 5,64 & 687889675 & 2,01 \\
\hline & 195 & 100,00 & 34209129094 & 100,00 \\
\hline
\end{tabular}

